\title{
The Evolution of Income Distribution in Brazil in the Agricultural and the Non-agricultural Sectors
}

\author{
Rodolfo Hoffmann ${ }^{1, *}$, Régis B. de Oliveira ${ }^{2}$ \\ ${ }^{1}$ Department of Economics, Administration and Sociology, University of São Paulo - ESALQ, Piracicaba, São Paulo, Brazil \\ ${ }^{2}$ Ministry of Agrarian Development, Brasília, Federal District, Brazil \\ *Corresponding author: hoffmannr@usp.br
}

Received September 02, 2014; Revised September 06, 2014; Accepted September 08, 2014

\begin{abstract}
The paper analyzes the characteristics and evolution of income distribution in the Brazilian agricultural sector, comparing it with the overall distribution or with the non-agricultural sector, considering two dimensions: the per capita household income and the income of occupied persons. The main data source is the National Household Sample Survey (PNAD). In order to fulfill this purpose, the per capita household income was divided into nine components (for Brazil and considering only the agricultural households) to evaluate their contributions to the decrease in inequality. In the second part, the paper analyzes the characteristics of occupied persons and the determining factors of their income, always comparing the agricultural and non-agricultural sectors. The estimated effects were analyzed over the period 1992-2012, adjusting one earnings equation for each year. In both cases (per capita household income and earnings of occupied persons), the agricultural sector showed a markedly different behavior. Regarding the per capita household income, though from 2001 to 2009 the rate of reduction in inequality among agricultural households is similar to the one observed in Brazil as a whole, the determinants associated with this reduction are clearly different in the agricultural sector. Concerning the income of occupied persons, the reduction in inequality is less intense and more irregular in the agricultural sector. The various factors that determine the income of occupied persons also presented distinct behaviors for the agricultural and non-agricultural sectors.
\end{abstract}

Keywords: per capita household income, occupied persons, agriculture, Brazil

Cite This Article: Rodolfo Hoffmann, and Régis B. de Oliveira, "The Evolution of Income Distribution in Brazil in the Agricultural and the Non-agricultural Sectors." World Journal of Agricultural Research, vol. 2, no. 5 (2014): 192-204. doi: 10.12691/wjar-2-5-1.

\section{Introduction}

In the recent period, the Brazilian economy showed important social changes. Even though it is still one of the most unequal economies of the world, an important decrease in inequality and extreme poverty is observed from 2001 on. Barros, Foguel and Ulyssea (2006 and 2007) present several studies that highlight this fact and show which are the main causes and determinants of this recent decline in poverty and inequality.

Among the determinants, the increase in transfers (pensions ${ }^{1}$ and cash transfers programs such as BolsaFamília) as a share of household income showed a significant contribution to the decrease in inequality. Besides transfers, changes in the labor market were also important, such as the increase in the average income of

\footnotetext{
${ }^{1}$ Overall official pensions, however, are a regressive component of the total household income, and contributed to increase inequality from 2001 to 2007, according to Hoffmann (2009). Hoffmann (2010 and 2013) show that pensions paid by the Official Social Security (INSS in the acronym in Portuguese) for the private sector workers are a progressive component of the household income, but pensions of civil servants are a strongly regressive component.
}

occupied persons, the reduction of the income differentials associated with different levels of education, the decrease in inequality between geographical regions, the expansion of the formal sector in the labor market and the systematic growth of the real national minimum wage.

Considering the recent decline in inequality in Brazil, this paper analyzes more accurately its determinants, comparing the agricultural and non-agricultural sectors. The agricultural sector is very heterogeneous, with strong differences between geographic locations and particular characteristics of the production process. Additionally, the changes in this sector occur more slowly, as illustrated by the fact that the level of schooling of agriculture workers is still far below the national average.

Thus, the paper analyzes the evolution of the income distribution in the agricultural sector in two dimensions: the evolution of the composition of the household income and occupied persons earnings, comparing the agricultural sector with Brazil's total economy or with the nonagricultural sector. As the income from work (earnings) is still the main share of household income, it will be examined in more detail.

Due to the lack of studies discussing the income distribution specifically for the agricultural sector, the paper will not focus in any specific relation, providing 
general information for households and occupied persons in this sector.

The paper is organized as follows: the next section shows the recent changes in the per capita household income distribution; the third section analyses the evolution of earnings, schooling and other characteristics of occupied persons in the agricultural and the nonagricultural sectors; in the fourth section earnings equations are adjusted for each year (in the period 19922012), in order to analyze the evolution of the effects of several factors on earnings; the corresponding methodology is described in each section; a short fifth section shows the changes in inequality between regions and between Federal Units; the last section presents the conclusions.

\section{Changes in the per Capita Household Income Distribution}

The paper uses data from the National Household Sample Survey (PNAD) to analyze the evolution of the per capita household income distribution in Brazil in the last decades. In this section, the analysis is limited to the period 1995-2012, given that extremely high inflation rates, which make it difficult to analyze the evolution of real mean income, no longer occur from 1995 on, and that the 2012 PNAD is the last one available.

The per capita household income is defined as the ratio between the household income (that is, the sum of all incomes received from all sources by the persons in the household) and the number of persons in the household, excluding boarders, domestic employees and their relatives living in the employers' house.

All the monetary values are expressed in Reais ( $\mathrm{R} \$$ Brazilian currency) of September-October 2012. All the values prior to the 2012 PNAD were updated using the geometric mean of the National Index of Prices (INPC) in September and October in each year.

It is known that in such a survey the respondent tends to understate his income ${ }^{2}$ (the data is collected through a self-declaration questionnaire). The degree of understatement varies according to the type of income: it is smaller for formal payments (paid by the government) and for regular payments, and larger for informal and or irregular receipts.

The rural areas of the states of Rondônia, Acre, Amazonas, Roraima, Pará and Amapá (the former Northern region) were excluded from the sample, as they were not covered by PNAD before 2004. Thus, in this paper "Brazil" shall be understood as "Brazil, excluding the rural area of the former Northern region”. An outlier was excluded from the 2012 sample. $^{3}$

Table 1 shows the evolution of the main characteristics of the per capita household income distribution in Brazil from 1995 to 2012. Table 2 shows the same indicators, considering only households in which the reference

\footnotetext{
${ }^{2}$ See, for example, Hoffmann (1988).

${ }^{3}$ It is a household with a very high income in one of the poorest states of Brazil (Maranhão). The household has 3 persons, each one with monthly earnings equal to R\$220,000.
}

person's main activity is in the agricultural ${ }^{4}$ sector (agricultural households).

It should be noted that the "agricultural households" subsample excludes not only the households in which the reference person's main occupation is non-agricultural, but also the households in which the reference person is not occupied.

There is a large difference between the per capita income of the households classified as "agricultural" in comparison with all households. In 2012, the average per capita household income of Brazil was almost $80 \%$ higher than the average of the agricultural households. Moreover, half of the agricultural households showed a per capita household income under $\mathrm{R} \$ 289.0$ per month (i.e., less than one half of the national minimum wage - $\mathrm{R} \$ 622.0$ in September-October 2012). The comparison between the average and the median of per capita household income shows that despite the reduction in inequality, the distribution is still strongly asymmetric.

According to all the indicators, there is a tendency to reduce inequality, especially from 2001 on. ${ }^{5}$ The same can be observed in the period 2001-2009, in Table 2, considering only the agricultural households. However, from 2009 to 2011 we observe a substantial increase of inequality for the agricultural households.

According to Table 1 and Table 2, rates of growth of the average (and the median) per capita household income are much higher for agricultural households in both subperiods (1995-2003 and 2003-2012). Meanwhile the decrease in inequality for agricultural households was below the observed for Brazil as a whole. Despite the decline in inequality in both cases, the income share appropriated by the poorest $50 \%$ increased less in the case of the agricultural households in the period 1995-2003 and also in the period 2003-2012. The decrease in inequality among agricultural households occurred mainly through changes in the income shares of the richest strata.

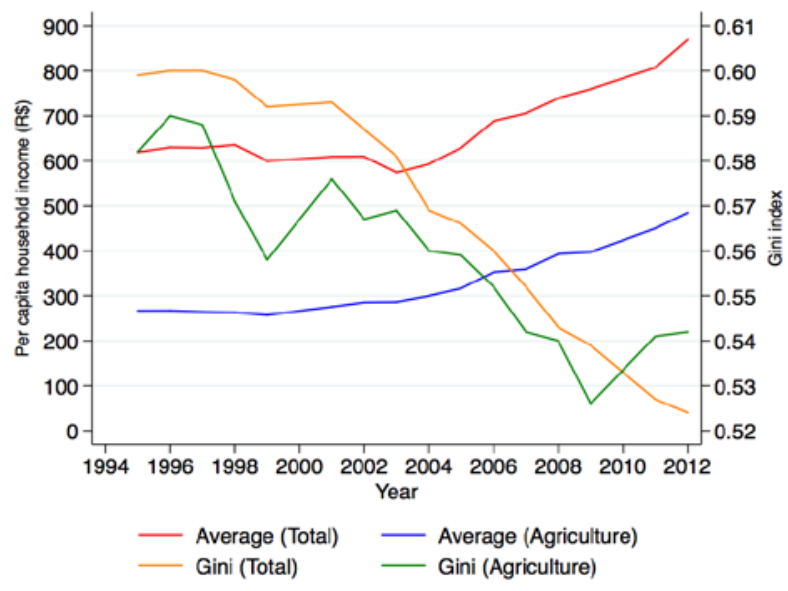

Figure 1. Average and Gini index of per capita household income, Brazil and only agricultural households, from 1995 to 2012

\footnotetext{
${ }^{4}$ Only permanent private households (variable V0201 = 1) were considered. The household is considered "agricultural" if the reference person's main job is in the agricultural sector- variable V4709 = 1 (until the 2001 PNAD) or variable V4809 = 1 (from 2002 on). All estimates were computed using the weights or sample expansion factors available in the data files.

${ }^{5}$ However, the Theil $T$, an inequality measure very sensitive to changes in the upper tail of the distribution, increases from 2011 to 2012.
} 
Figure 1 illustrates the evolution of the average per capita household income and the Gini index for total Brazil and for agricultural households alone. It should be noted that from 1995 to 2003 the overall average decreases but the average of the agricultural households increases. This movement is certainly related to the modernization and productivity rise in Brazilian agriculture.

Figure 1 shows the well-known process of systematic reduction in inequality of the distribution of the per capita household income in Brazil from 2001 on, with a decrease of the Gini index from 0.593 to 0.524 . Considering the period 1995-2012, the reduction in the Gini index is slightly bigger, because its value is 0.599 in 1995 . For the agricultural households, the changes in the Gini index are more irregular (partly due to the smaller sample) and, additionally, the reduction in inequality was systematic only from 2003 to 2009. It can be noted, in Figure 1, that during this period the lines representing the changes in the Gini index of both distributions fall almost in parallel. However, as will be seen below, the factors associated with this reduction are not the same. And in 2011 and 2012 the Gini index for the agricultural households becomes greater than the Gini index for all households.

Table 1. Per capita household income distribution in Brazil $^{(1)}$, from 1995 to 2012: average, median and inequality measures

\begin{tabular}{|c|c|c|c|c|c|c|c|c|c|c|}
\hline \multirow[b]{2}{*}{ Year } & \multirow{2}{*}{ Average $^{(2)}$} & \multirow{2}{*}{$\operatorname{Median}^{(2)}$} & \multicolumn{4}{|c|}{ Inequality measures } & \multicolumn{4}{|c|}{ \% of income appropriated by } \\
\hline & & & Gini $(G)$ & Mehran (M) & Piesch $(P)$ & Theil (T) & Poorest $50 \%$ & Richest $10 \%$ & Richest 5\% & Richest $1 \%$ \\
\hline 1995 & 619.2 & 302.5 & 0.599 & 0.730 & 0.533 & 0.727 & 12.5 & 47.7 & 34.0 & 13.7 \\
\hline 1996 & 629.9 & 309.4 & 0.600 & 0.735 & 0.533 & 0.726 & 12.2 & 47.3 & 33.6 & 13.4 \\
\hline 1997 & 628.9 & 309.5 & 0.600 & 0.734 & 0.533 & 0.731 & 12.2 & 47.5 & 33.8 & 13.6 \\
\hline 1998 & 635.6 & 319.0 & 0.598 & 0.730 & 0.532 & 0.728 & 12.4 & 47.6 & 34.0 & 13.8 \\
\hline 1999 & 599.6 & 306.3 & 0.592 & 0.724 & 0.526 & 0.706 & 12.8 & 47.1 & 33.4 & 13.1 \\
\hline 2001 & 609.0 & 307.1 & 0.593 & 0.725 & 0.527 & 0.719 & 12.7 & 47.2 & 33.8 & 13.8 \\
\hline 2002 & 609.3 & 312.4 & 0.587 & 0.718 & 0.522 & 0.705 & 13.1 & 46.8 & 33.4 & 13.4 \\
\hline 2003 & 573.7 & 302.9 & 0.581 & 0.713 & 0.515 & 0.680 & 13.3 & 46.0 & 32.7 & 13.0 \\
\hline 2004 & 592.9 & 320.1 & 0.569 & 0.700 & 0.503 & 0.656 & 14.0 & 45.0 & 31.9 & 12.8 \\
\hline 2005 & 629.2 & 343.6 & 0.566 & 0.697 & 0.501 & 0.651 & 14.2 & 45.0 & 32.0 & 12.9 \\
\hline 2006 & 688.3 & 383.1 & 0.560 & 0.690 & 0.495 & 0.635 & 14.6 & 44.5 & 31.6 & 12.6 \\
\hline 2007 & 705.6 & 402.1 & 0.552 & 0.684 & 0.486 & 0.614 & 15.0 & 43.5 & 30.8 & 12.3 \\
\hline 2008 & 739.3 & 434.0 & 0.543 & 0.674 & 0.477 & 0.594 & 15.5 & 42.8 & 30.2 & 12.0 \\
\hline 2009 & 759.5 & 452.3 & 0.539 & 0.670 & 0.473 & 0.588 & 15.7 & 42.5 & 30.0 & 12.0 \\
\hline 2011 & 807.3 & 502.5 & 0.527 & 0.659 & 0.462 & 0.560 & 16.4 & 41.5 & 29.3 & 11.6 \\
\hline 2012 & 869.1 & 540.7 & 0.524 & 0.654 & 0.460 & 0.578 & 16.7 & 41.5 & 29.5 & 12.2 \\
\hline$\Delta \% 95-03$ & -7.3 & 0.1 & -3.0 & -2.3 & -3.4 & -6.5 & 6.4 & -3.6 & -3.8 & -5.1 \\
\hline$\Delta \%$ 03-12 & 51.5 & 78.5 & -9.8 & -8.3 & -10.7 & -15.0 & 25.6 & -9.8 & -9.8 & -6.2 \\
\hline
\end{tabular}

(1) Excluding the rural area of the former Northern region.

(2) In Reais (Brazilian Currency - R\$) of September-October 2012.

Table 2. Per capita household income distribution in Brazil ${ }^{(1)}$, from 1995 to 2012, considering only agricultural households: average, median and inequality measures

\begin{tabular}{|c|c|c|c|c|c|c|c|c|c|c|}
\hline \multirow{2}{*}{ Year } & \multirow{2}{*}{ Average $^{(2)}$} & \multirow{2}{*}{ Median $^{(2)}$} & \multicolumn{4}{|c|}{ Inequality measures } & \multicolumn{4}{|c|}{ \% of income appropriated by } \\
\hline & & & $\operatorname{Gini}(G)$ & Mehran (M) & Piesch $(P)$ & Theil (T) & Poorest $50 \%$ & Richest $10 \%$ & Richest 5\% & Richest 1\% \\
\hline 1995 & 266.7 & 141.2 & 0.582 & 0.702 & 0.522 & 0.779 & 14.1 & 47.9 & 36.5 & 17.4 \\
\hline 1996 & 267.0 & 136.8 & 0.590 & 0.713 & 0.529 & 0.811 & 13.5 & 48.1 & 36.6 & 18.0 \\
\hline 1997 & 264.4 & 136.3 & 0.588 & 0.709 & 0.527 & 0.789 & 13.7 & 48.2 & 36.4 & 17.3 \\
\hline 1998 & 263.0 & 141.8 & 0.571 & 0.693 & 0.510 & 0.742 & 14.4 & 46.5 & 34.9 & 16.9 \\
\hline 1999 & 257.4 & 141.1 & 0.558 & 0.682 & 0.496 & 0.676 & 15.1 & 45.2 & 33.5 & 15.1 \\
\hline 2001 & 275.5 & 146.7 & 0.576 & 0.700 & 0.514 & 0.743 & 14.1 & 46.5 & 35.0 & 16.7 \\
\hline 2002 & 285.4 & 154.6 & 0.567 & 0.689 & 0.506 & 0.737 & 14.7 & 46.0 & 34.5 & 17.0 \\
\hline 2003 & 286.1 & 155.2 & 0.569 & 0.694 & 0.507 & 0.729 & 14.4 & 45.8 & 34.1 & 16.7 \\
\hline 2004 & 299.7 & 165.7 & 0.560 & 0.685 & 0.497 & 0.697 & 14.9 & 45.0 & 33.3 & 15.7 \\
\hline 2005 & 316.7 & 175.9 & 0.559 & 0.682 & 0.497 & 0.719 & 15.1 & 45.1 & 33.8 & 16.5 \\
\hline 2006 & 352.6 & 203.1 & 0.552 & 0.679 & 0.488 & 0.678 & 15.1 & 43.8 & 32.4 & 15.7 \\
\hline 2007 & 359.2 & 207.7 & 0.542 & 0.675 & 0.475 & 0.603 & 15.3 & 42.1 & 30.1 & 12.8 \\
\hline 2008 & 393.1 & 232.4 & 0.540 & 0.670 & 0.476 & 0.646 & 15.7 & 42.5 & 31.2 & 14.9 \\
\hline 2009 & 397.2 & 243.1 & 0.526 & 0.661 & 0.459 & 0.579 & 16.0 & 40.4 & 28.8 & 13.0 \\
\hline 2011 & 449.9 & 266.6 & 0.541 & 0.675 & 0.474 & 0.623 & 15.3 & 41.9 & 30.2 & 13.6 \\
\hline 2012 & 484.8 & 289.0 & 0.542 & 0.673 & 0.476 & 0.687 & 15.5 & 42.2 & 31.0 & 15.7 \\
\hline$\Delta \% 95-03$ & 7.3 & 9.9 & -2.2 & -1.1 & -2.9 & -6.4 & 2.1 & -4.4 & -6.6 & -4.0 \\
\hline$\Delta \% 03-12$ & 69.5 & 86.2 & -4.7 & -3.0 & -6.1 & -5.8 & 7.6 & -7.9 & -9.1 & -6.0 \\
\hline \multicolumn{11}{|c|}{ Source: National Household Sample Survey (PNAD) } \\
\hline & & & & xcluding the $\mathrm{r}$ & ral area of th & former Nol & hern region. & & & \\
\hline
\end{tabular}

It was verified that in the period 1995-2012 the percentage of total income received by the richest hundredth decreased in both populations: from $13.7 \%$ to $12.2 \%$ for total Brazil and from $17.4 \%$ to $15.7 \%$ for agricultural households, where this percentage is always higher. The stronger concentration of income in the top of the distribution for agricultural households may be related to the very high inequality of land ownership in Brazil, but capital distribution is also very concentrated in the nonagricultural sector. In part, the higher concentration on the top of the distribution of income of agricultural households may be due to the higher underestimation of some types of income in the non-agricultural sector. For agricultural households, a substantial part of profits and 
interest is probably declared as part of farmers "earnings", but in the non-agricultural sector most profits are not included in households' income and interest and dividends are mostly not declared.

To analyze the factors associated with the changes in the Gini index, a method of decomposition of this index briefly described here will be used. If the per capita household income of the $i$-th person $\left(x_{i}\right)$ has $k$ components ( $x_{h i}$, with $h=1, \ldots, k$ ), so that

$$
x_{i}=\sum_{h=1}^{k} x_{h i} \text { for every } i,
$$

it can be deduced that the Gini index is equal to a weighted average of the concentration ratios of each component:

$$
G=\sum_{h=1}^{k} \phi_{h} C_{h}
$$

with $\phi_{h}$ indicating the share of the $h$-th component in total income and $C_{h}$ indicating the respective concentration ratio.

Being $\mu$ the average of per capita household income and $\mu_{h}$ the average of $x_{h i}$ for the $n$ persons of the population, the Gini index can be defined as

$$
G=\frac{2}{n \mu} \operatorname{cov}\left(i, x_{i}\right)
$$

and the concentration ratios are

$$
C_{h}=\frac{2}{n \mu_{h}} \operatorname{cov}\left(i, x_{h i}\right)
$$

Using subscripts 1 and 2 to indicate the values of $\phi_{h}$, $C_{h}$ and $G$ in two different periods and defining

$$
\begin{aligned}
\phi_{h}^{*} & =\frac{1}{2}\left(\phi_{1 h}+\phi_{2 h}\right), \\
C_{h}^{*} & =\frac{1}{2}\left(C_{1 h}+C_{2 h}\right)
\end{aligned}
$$

and

$$
G^{*}=\frac{1}{2}\left(G_{1}+G_{2}\right)
$$

the change in the Gini index $\left(\Delta G=G_{2}-G_{1}\right)$ can be decomposed as follows: ${ }^{6}$

$$
\Delta G=\sum_{h=1}^{k}\left(C_{h}^{*}-G^{*}\right) \Delta \phi_{h}+\sum_{h=1}^{k} \phi_{h}^{*} \Delta C_{h}
$$

On the right-hand side of expression (8), the first term is the sum of the composition-effects, associated with changes in $\phi_{h}$, and the second term is the sum of the concentration-effects, due to changes in $C_{h}$.

\footnotetext{
${ }^{6}$ This dynamic decomposition of the Gini index was first used by Hoffmann(2006) and Soares(2006). The deduction of this expression is presented in Hoffmann (2006, 2011 and 2013b).
}

The contribution of the $h$-th income component to the change in the Gini index is given by

$$
\left(C_{h}^{*}-G^{*}\right) \Delta \phi_{h}+\phi_{h}^{*} \Delta C_{h}
$$

Thus it is possible to analyze the contributions of the different components of the per capita household income to the change in the Gini index in a given time period.

Here the per capita household income will be divided into nine components ${ }^{7}$, described as follows:

CSM: earnings of civil servants and military personnel

EMP: earnings of other employees

SLF: earnings of self-employed workers

YER: earnings of employers

PE1: official pensions paid by the official social security (INSS ${ }^{8}$ ) or by government overall

PE2: other pensions

DON: donations received from other households

RNT: rents

IBF: interest, shares, government transfers (such as those from the BolsaFamília program) and other incomes.

Table 3 shows the shares $\left(\phi_{h}\right)$ of these nine components of the per capita household income in Brazil in 1995, 2001, 2009 and 2012 and also the correspondent concentration ratios $\left(C_{h}\right)$. Table 4 presents the same results considering only the agricultural households.

For all households, the private sector employees' earnings is clearly the main component, representing around $40 \%$ of total household income. The earnings of civil servants and military personnel represent around $10 \%$, so that nearly half of total income corresponds to employees' earnings. However, for the agricultural households, in 1995 the share of earnings of the selfemployed was still larger, due to the importance of family farms.

Table 5 shows the decomposition of the change in the Gini index for selected periods. Considering all households in the period 2001-2012, 44\% of the decrease in the Gini index is associated with changes in earnings of the private sector employees and $18 \%$ is due to changes in the IBF component (interests, shares and transfers). This last relatively small component increased $160 \%$ in this period and the respective concentration rate declined strongly (from 0.526 to 0.026 ). This can be explained by the large expansion of government transfers, especially the BolsaFamília ${ }^{9}$ program.

Official pensions (PE1) contributed substantially to the decrease in inequality from 2001 to 2012 as well. It can be verified that the larger part of this effect is associated with the rise in the real value of the national minimum wage (MW), which, by law, is the floor value of official pensions. The PE1 income was split into two ranges, creating a subcomponent with pensions near or below the MW (below the rounded integer value closest to 1.095 times the MW), and it was verified that the share of these poorer pensions in per capita household income increased

\footnotetext{
${ }^{7}$ Note that the components of the household income must be exhaustive and mutually exclusive.

${ }^{8}$ Portugueseacronym for Instituto Nacional do Seguro Social (theBrazilian Social Security Office)

${ }^{9}$ There are many studies showing this relation. They disaggregate the IBF component, separating transfers from other incomes included in this component: Soares et al. (2006), Barros, Carvalho and Franco (2007) and Hoffmann (2013a).
} 
from $4.11 \%$ in 2001 to $6.58 \%$ in 2012, while its concentration ratio increased from 0.088 to 0.151 . The overall effect of this clearly progressive subcomponent explains $10.8 \%$ of $\Delta G=-0.069$. The other PE1 subcomponent is regressive ( $C_{h}=0.762$ in 2001 and $C_{h}=0.734$ in 2012), but also contributed to decrease the inequality (total effect equal to $9.5 \%$ of $\Delta G=-0.069$ ).

Table 3. Share and concentration ratio of each component of the per capita household income, in Brazil, in selected years

\begin{tabular}{|c|c|c|c|c|c|c|c|c|}
\hline \multirow{2}{*}{ Component } & \multicolumn{4}{|c|}{ Share of household income $\left(100 \phi_{h} \%\right)$} & \multicolumn{4}{|c|}{ Concentration ratio $\left(C_{h}\right)$} \\
\hline & 1995 & 2001 & 2009 & 2012 & 1995 & 2001 & 2009 & 2012 \\
\hline 1. CSM & 10.10 & 9.97 & 11.29 & 10.57 & 0.734 & 0.739 & 0.746 & 0.730 \\
\hline 2. EMP & 39.86 & 39.73 & 40.88 & 42.13 & 0.508 & 0.498 & 0.435 & 0.430 \\
\hline 3. SLF & 18.95 & 16.46 & 13.36 & 15.02 & 0.516 & 0.523 & 0.473 & 0.511 \\
\hline 4. YER & 13.14 & 11.73 & 10.65 & 9.29 & 0.863 & 0.860 & 0.836 & 0.853 \\
\hline 5. PE1 & 13.34 & 17.11 & 18.81 & 17.93 & 0.582 & 0.600 & 0.564 & 0.520 \\
\hline 6. PE2 & 0.91 & 1.47 & 1.32 & 1.15 & 0.649 & 0.620 & 0.493 & 0.461 \\
\hline 7. DON & 0.58 & 0.68 & 0.44 & 0.27 & 0.399 & 0.393 & 0.392 & 0.322 \\
\hline 8. RNT & 2.25 & 1.93 & 1.56 & 1.25 & 0.813 & 0.797 & 0.774 & 0.804 \\
\hline 9. IBF & 0.88 & 0.92 & 1.69 & 2.40 & 0.789 & 0.526 & -0.105 & 0.026 \\
\hline Total & 100.00 & 100.00 & 100.00 & 100.00 & 0.599 & 0.593 & 0.539 & 0.524 \\
\hline
\end{tabular}

Table 4. Share and concentration ratio of each component of the per capita household income for agricultural households, in Brazil, in selected years

\begin{tabular}{|c|c|c|c|c|c|c|c|c|}
\hline \multirow{2}{*}{ Component } & \multicolumn{4}{|c|}{ Share of household income $\left(100 \phi_{h} \%\right)$} & \multicolumn{4}{|c|}{ Concentration ratio $\left(C_{h}\right)$} \\
\hline & 1995 & 2001 & 2009 & 2012 & 1995 & 2001 & 2009 & 2012 \\
\hline 1. CSM & 2.34 & 2.56 & 3.03 & 2.88 & 0.791 & 0.724 & 0.670 & 0.634 \\
\hline 2. EMP & 28.51 & 29.09 & 31.56 & 30.85 & 0.382 & 0.393 & 0.372 & 0.402 \\
\hline 3. SLF & 32.03 & 27.14 & 23.40 & 24.38 & 0.506 & 0.507 & 0.538 & 0.595 \\
\hline 4. YER & 19.39 & 17.40 & 13.31 & 12.85 & 0.918 & 0.923 & 0.920 & 0.945 \\
\hline 5. PE1 & 14.08 & 19.06 & 21.67 & 21.15 & 0.609 & 0.627 & 0.588 & 0.594 \\
\hline 6. PE2 & 0.47 & 0.46 & 0.63 & 0.65 & 0.816 & 0.589 & 0.501 & 0.564 \\
\hline 8. RNT & 1.90 & 2.05 & 1.42 & 1.25 & 0.891 & 0.912 & 0.878 & 0.898 \\
\hline 9. IBF & 0.79 & 1.77 & 4.68 & 5.83 & 0.815 & 0.153 & -0.074 & -0.130 \\
\hline Total & 100.00 & 100.00 & 100.00 & 100.00 & 0.582 & 0.576 & 0.526 & 0.542 \\
\hline
\end{tabular}

Table 5. Decomposition of the change in the Gini index of the per capita household income distribution in Brazil

\begin{tabular}{|c|c|c|c|c|c|c|c|c|c|}
\hline \multirow{3}{*}{ Component } & \multicolumn{6}{|c|}{ All households } & \multirow{2}{*}{\multicolumn{3}{|c|}{$\begin{array}{c}\text { Agricultural households } \\
2001-2009 \\
\Delta G=-0.050\end{array}$}} \\
\hline & \multicolumn{3}{|c|}{$\begin{array}{c}2001-2012 \\
\Delta G=-0.069\end{array}$} & \multicolumn{3}{|c|}{$\begin{array}{c}2001-2009 \\
\Delta G=-0.055\end{array}$} & & & \\
\hline & $\Delta \phi^{(1)}$ & $\Delta C^{(2)}$ & Total $^{(3)}$ & $\Delta \phi^{(1)}$ & $\Delta C^{(2)}$ & Total $^{(3)}$ & $\Delta \phi^{(1)}$ & $\Delta C^{(2)}$ & Total $^{(3)}$ \\
\hline 1. CSM & -1.5 & 1.2 & -0.3 & -4.3 & -1.3 & -5.6 & -1.4 & 3.1 & 1.7 \\
\hline 2. EMP & 3.3 & 40.7 & 44.0 & 2.1 & 47.1 & 49.2 & 8.4 & 13.0 & 21.3 \\
\hline 3. SLF & -0.9 & 2.7 & 1.9 & -3.8 & 13.5 & 9.7 & -2.1 & -15.9 & -18.0 \\
\hline 4. YER & 10.5 & 1.1 & 11.6 & 5.6 & 4.9 & 10.5 & 30.5 & 1.1 & 31.6 \\
\hline 5. PE1 & 0.0 & 20.3 & 20.3 & -0.5 & 12.0 & 11.5 & -3.0 & 15.9 & 12.9 \\
\hline 6. PE2 & -0.1 & 3.0 & 2.9 & 0.0 & 3.3 & 3.2 & 0.0 & 1.0 & 1.0 \\
\hline 7. DON & -1.2 & 0.5 & -0.7 & -0.8 & 0.0 & -0.8 & -1.1 & 0.4 & -0.7 \\
\hline 8. RNT & 2.4 & -0.2 & 2.2 & 1.5 & 0.8 & 2.2 & 4.3 & 1.2 & 5.5 \\
\hline 9. IBF & 6.0 & 12.0 & 18.0 & 5.0 & 15.1 & 20.0 & 30.0 & 14.7 & 44.7 \\
\hline Total & 18.5 & 81.5 & 100.0 & 4.7 & 95.3 & 100.0 & 65.7 & 34.3 & 100.0 \\
\hline
\end{tabular}

(1) Composition effect, as percent of $\Delta G$

(2) Concentration effect, as percent of $\Delta G$

(3) Total effect of the component, as percent of $\Delta G$

Table 5 also shows the same type of decomposition of the change in the Gini index considering the period: 20012009. The major contributions to reduce inequality are still associated with the components EMP, IBF and PE1. Note the weaker effect of PE1 (indicating that rises in the floor value of official pensions is becoming less effective as a measure to decrease income inequality) and also the negative effect (a contribution to inequality increase) of military and civil servants' wages ${ }^{10}$.

As shown in Figure 1, in the period from 2001 to 2009 the Gini index of the per capita household income distribution in Brazil and the corresponding Gini index considering only agricultural households fell almost in

\footnotetext{
${ }^{10}$ For a detailed analysis of the influence of public servants' earnings on the per capita household income distribution in Brazil from 1995 to 2009, see Daré (2011).
}

parallel, showing a very similar evolution. However, the components of these reductions of the Gini index are quite different, as can be seen in Table 5. Many differences are simply due to the fact that the agricultural households are relatively poor, as shown by the lines of the average per capita household income in Figure 1. Thus, the IBF component (which includes income from the BolsaFamília program) is much more important for agricultural households and its contribution to the decline of the Gini index between 2001 and 2012 is almost 45\% (last column of Table 5).

The contribution of the EMP component (earnings of employees), which is $49.2 \%$ for all households, falls to only 21.3 when considering only the agricultural households. Partially, this is due to the fact that the 
minimum wage, which functions in general as a "lighthouse" for the lower wages ${ }^{11}$, has no such effect for the informal ${ }^{12}$ employees in the Brazilian agricultural sector, as shown in Oliveira (2010) and Oliveira and Hoffmann (2013 a).

Table 5 indicates that, for the agricultural households, the YER component (earnings of employers) contributed to $31.6 \%$ of the decrease in the Gini index between 2001 and 2009. This is essentially a composition effect due to the substantial reduction of the participation (from 17.4\% to $13.3 \%$ ) of a strongly regressive component of the per capita household income. An important part of this reduction may be associated with changes in the legal structure of production units, which have allowed transforming employers’ earnings into executive salaries.

\section{Occupied Persons Earnings}

The distinction between agricultural and nonagricultural sectors becomes clearer when considering only occupied persons. Thus, this section analyses the distribution of earnings (including all jobs of each occupied person and excluding unpaid workers). In the data files used, only persons that are 10 or more years old are classified as occupied or not. As it is intended to use subsequently the same sample to estimate earnings equations, in this section the observations that do not contain information about any of the variables included in those equations are excluded.

Therefore, are excluded from the sample persons with no declaration of age, schooling, earnings, color, working hours per week or those classified as "worker in production for own consumption", "worker in construction for own use" or "unpaid workers". Equally excluded are the persons whose color is declared as "indigenous" (due to the very small number in the sample) and those whose working hours (in all jobs) are either less than 15 or above 98 hours per week.

It is important to bear in mind that "labor income" (or earnings), as defined in the survey, includes the salary of employees but in the case of employers and self-employed it includes "monthly withdrawals" from their businesses. Obviously, in the case of a farmer, for instance, the "earnings" can include profits and land rent. Thus, these earnings should not be confused with wages or with the classic-Marxist concept of labor income. It would be better to call it "income from the activity" performed by the person, but it was preferred to keep the terminology already established by the Brazilian Census Bureau (IBGE).

In the 2012 PNAD it is found that, for the data previously delimited, $20.8 \%$ of occupied persons were self-employed and $4.0 \%$ were employers. Thus, about 3/4 of the occupied persons are employees. In the agricultural

\footnotetext{
${ }^{11}$ Souza and Baltar (1979) first announced the "lighthouse effect". According to this assumption the minimum wage works as a signal for wage bargaining even in the informal sector. For more recent research on minimum wage in Brazil (and Latin America) and this effect, see: Maloney and Mendez (2004), Lemos (2003) and Neumark, Cunningham and Siga (2003).

${ }^{12}$ According to Oliveira and Hoffmann (2013), the informal employees represented, in 2009, 64.1\% of all agricultural employees.
}

sector almost $43 \%$ of occupied persons with positive earnings were self-employed.

Figure 2 shows the evolution of the average and of the Gini index of the earnings distribution, considering all occupied persons in Brazil, in the agricultural sector and in the non-agricultural sector. It can be noted that for the total economy and for the non-agricultural sector the average decreases from 1996 to 2004 and then rises systematically until 2012. In Figure 1 the decline in the average per capita household income from 1996 to 2004 is less intense and the growth from 2004 on is stronger due to the systematic reduction of the number of members per household, which falls from 3.87 in 1995 to 3.10 in 2012.

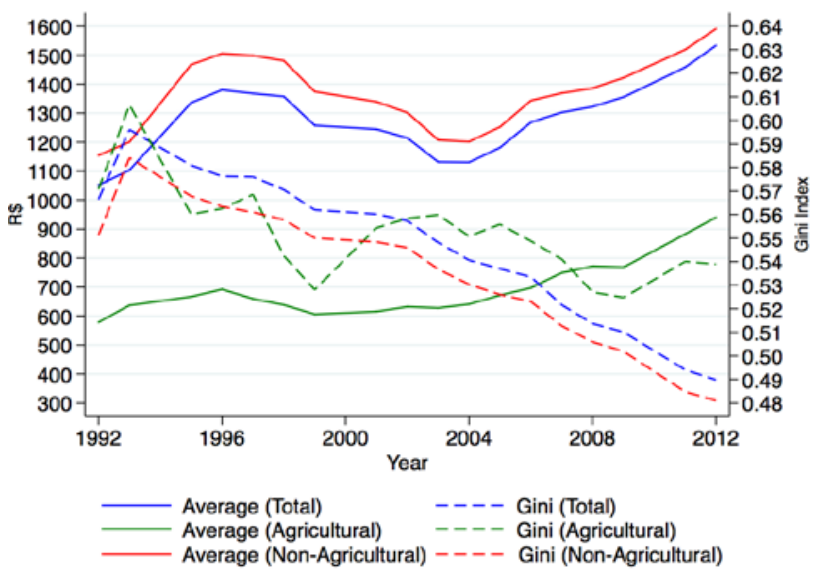

Figure 2. Average and Gini index of the earnings distribution in Brazil, from 1992 to 2012: total, agricultural and non-agricultural sectors

Both average earnings and the Gini index have very similar trajectories for Brazil and for the non-agricultural sector, but the trajectories are different for the agricultural sector (Figure 2). In the 1999-2004 period the average falls in the non-agricultural sector but increases in the agricultural sector, a fact related to the end of the exchange-rate anchor in 1999 (with a devaluation of Brazilian currency), promoting exports of agricultural goods.

The Gini index for the total and for the non-agricultural sector decreased systematically from 1993 to 2012, but the behavior of the Gini index is more irregular in the agricultural sector, decreasing from 1993 to 1999 and increasing from 1999 to 2012.

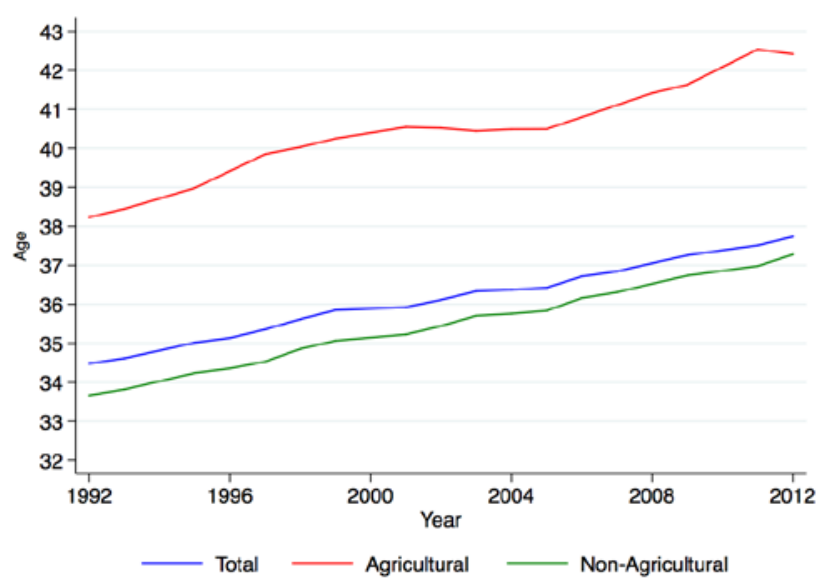

Figure 3. Growth of the mean age of occupied persons with positive earnings in Brazil, from 1992 to 2012: total, agricultural and nonagricultural sectors 
Figure 3 shows that the occupied persons' average age tends to grow and is always higher in the agricultural sector. The data presented are consistent with the wellknown trend of the population's aging. The younger generations in the agricultural sector look for nonagricultural occupations, expecting better wages and living conditions. Thus, the average age of occupied persons in agriculture is greater than the average of Brazil and of the non-agricultural sector.

Figure 4 shows that the average of weekly working hours tends to decrease and is always higher in the agricultural sector. The line for the number of hours worked in the agricultural sector is steeper, indicating a sharper rate of decline. These results are consistent with IPEA (2009), showing a reduction in the average hours of work in Brazil. The study also shows that the agricultural sector stands out, with a drop of $26.3 \%$ in the average number of hours of work between 1988 and $2007^{13}$.

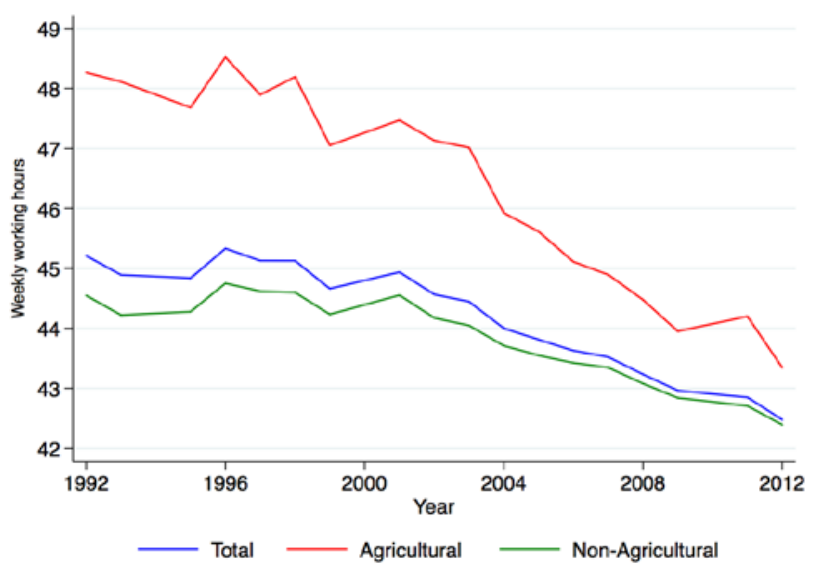

Figure 4. Evolution of the average weekly working hours of occupied persons with positive earnings in Brazil, from 1992 to 2012: total, agricultural and non-agricultural sectors

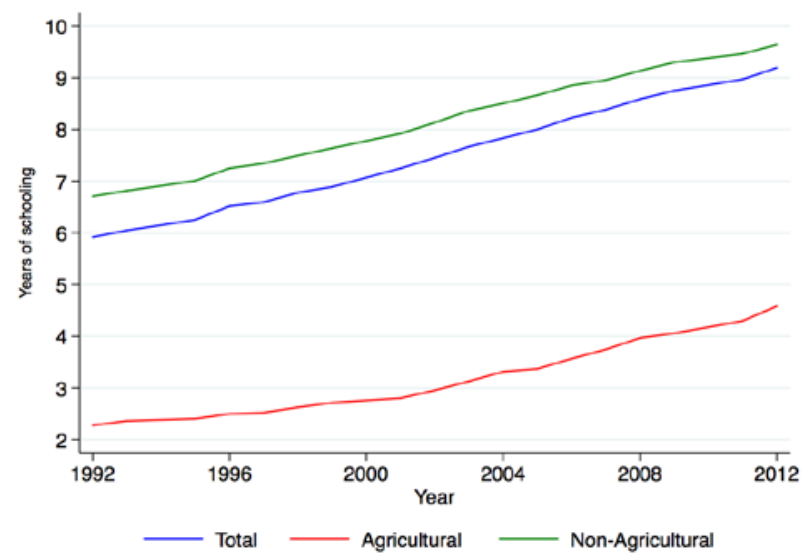

Figure 5. Growth of average schooling of occupied persons with positive earnings in Brazil, from 1992 to 2012: total, agricultural and nonagricultural sectors

\footnotetext{
${ }^{13}$ It should be mentioned that the 1988 National Constitution reduced the regular maximum of weekly working hours from 48 to 44 but the effect of this legal change was not immediately felt, especially in the agricultural sector. Moreover, there was an intense process of modernization in the agriculture sector in Brazil throughout the entire country (obviously with regional differences), increasing productivity and reducing the amount of labor demanded. These two facts are related to the decrease in the weekly hours of work in the agricultural sector.
}

In Figure 5 and Table 6 it is observed that mean schooling is much higher in the non-agricultural sector than in the agricultural sector (9.6 and 4.6 years, respectively, in 2012). In both cases there is a systematic growth ${ }^{14}$, but not with the same intensity. The ratio between the average schooling of non-agricultural and agricultural occupied persons falls from 2.9 in 1992-1997 to 2.1 in 2012 .

Table 6. Average and mean absolute deviation $(\Delta)$ of the distribution of schooling among occupied persons in Brazil, from 1992 to 2012: total, agricultural and non-agricultural sectors

\begin{tabular}{|c|c|c|c|c|c|c|}
\hline \multirow{2}{*}{ Year } & \multicolumn{2}{|c|}{ Total } & \multicolumn{2}{c|}{$\begin{array}{c}\text { Agricultural } \\
\text { sector }\end{array}$} & \multicolumn{2}{c|}{$\begin{array}{c}\text { Non-agricultural } \\
\text { sector }\end{array}$} \\
\cline { 2 - 7 } & Average & $\Delta$ & Average & $\Delta$ & Average & $\Delta$ \\
\hline 1992 & 5.92 & 5.17 & 2.28 & 2.72 & 6.71 & 5.16 \\
\hline 1993 & 6.05 & 5.17 & 2.36 & 2.75 & 6.81 & 5.15 \\
\hline 1995 & 6.25 & 5.21 & 2.41 & 2.83 & 7.01 & 5.14 \\
\hline 1996 & 6.52 & 5.26 & 2.50 & 2.91 & 7.25 & 5.15 \\
\hline 1997 & 6.59 & 5.30 & 2.52 & 2.89 & 7.34 & 5.19 \\
\hline 1998 & 6.78 & 5.34 & 2.63 & 2.99 & 7.49 & 5.22 \\
\hline 1999 & 6.89 & 5.32 & 2.71 & 3.05 & 7.64 & 5.17 \\
\hline 2001 & 7.25 & 5.35 & 2.80 & 3.12 & 7.92 & 5.16 \\
\hline 2002 & 7.45 & 5.35 & 2.95 & 3.26 & 8.13 & 5.13 \\
\hline 2003 & 7.67 & 5.35 & 3.13 & 3.39 & 8.36 & 5.10 \\
\hline 2004 & 7.83 & 5.32 & 3.31 & 3.51 & 8.50 & 5.07 \\
\hline 2005 & 8.00 & 5.31 & 3.37 & 3.54 & 8.66 & 5.04 \\
\hline 2006 & 8.23 & 5.29 & 3.57 & 3.68 & 8.85 & 5.01 \\
\hline 2007 & 8.38 & 5.28 & 3.74 & 3.75 & 8.95 & 5.03 \\
\hline 2008 & 8.59 & 5.26 & 3.97 & 4.06 & 9.13 & 4.98 \\
\hline 2009 & 8.75 & 5.27 & 4.06 & 4.10 & 9.30 & 4.99 \\
\hline 2011 & 8.97 & 5.29 & 4.30 & 4.32 & 9.46 & 5.02 \\
\hline 2012 & 9.19 & 5.14 & 4.58 & 4.27 & 9.64 & 4.90 \\
\hline
\end{tabular}

Besides the average schooling, Table 6 shows the value of the mean absolute difference $(\Delta)$, which is a measure of the dispersion of the distribution (such as the standard deviation, $\sigma$ ). It is important to distinguish the concepts of dispersion and inequality of a distribution, because, as will be explained in the next section, it is schooling dispersion, and not schooling inequality, which is directly related to income inequality. Note that there are inequality measures, such as the Gini index $(G)$ and the coefficient of variation $(C)$, which are measures of relative dispersion, since

$$
G=\frac{\Delta}{2 \mu} \text { and } C=\frac{\sigma}{\mu}
$$

with $\mu$ indicating the mean of the distribution.

In Figure 6 it is observed that the inequality of the distribution of occupied persons' schooling shows a declining trend both in the agricultural sector and in the non-agricultural sector. However, Figure 7 shows that the dispersion of schooling tends to increase in the agricultural sector and in the non-agricultural sector it tends to decrease from 1998 on.

Figure 8 presents the relation between the mean absolute difference $(\Delta)$ and the mean schooling in Brazil, based on the values of the two first columns of Table 6 . The shape of the curve is almost the same if, instead of $\Delta$, the standard deviation of schooling is used, as done by Barros, Franco and Mendonça (2007) and Lorel (2008). This empirically observed relation resembles the famous

\footnotetext{
${ }^{14}$ Schooling is defined by the most advanced degree achieved by the person, with 0 (zero) meaning "no schooling or less than one year". For the category "15 years or more" (variable V4703 or V4803 of PNAD) was attributed the value 17 .
} 
and controversial Kuznets’ Curve relating inequality and average of the income distribution.

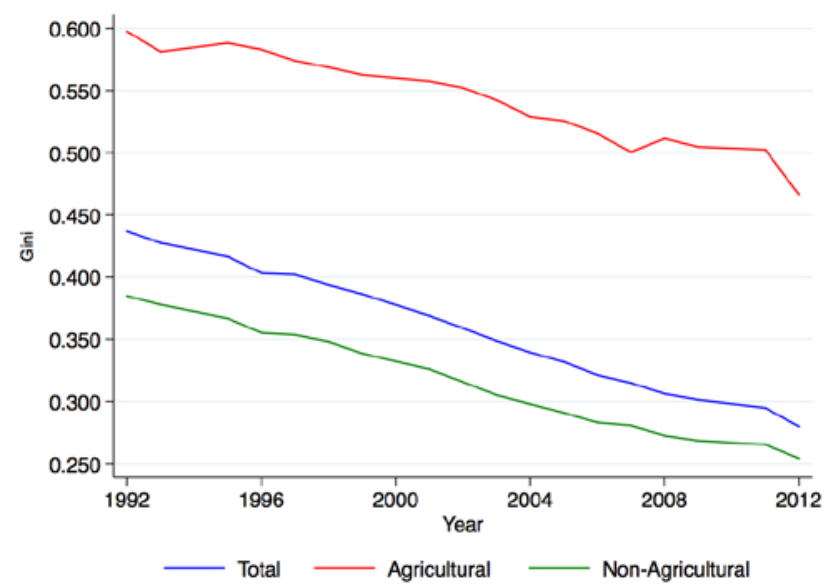

Figure 6. The decreasing trend of the Gini index of occupied persons' schooling distribution in Brazil, from 1992 to 2012: total, agricultural sector and non-agricultural sectors

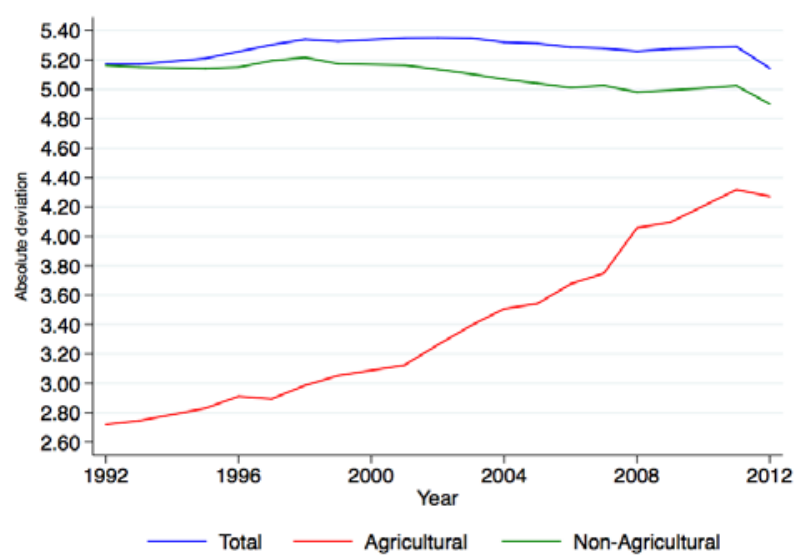

Figure 7. Variation of the mean absolute deviation of occupied persons' schooling in Brazil, from 1992 to 2012: total, agricultural sector and nonagricultural sectors

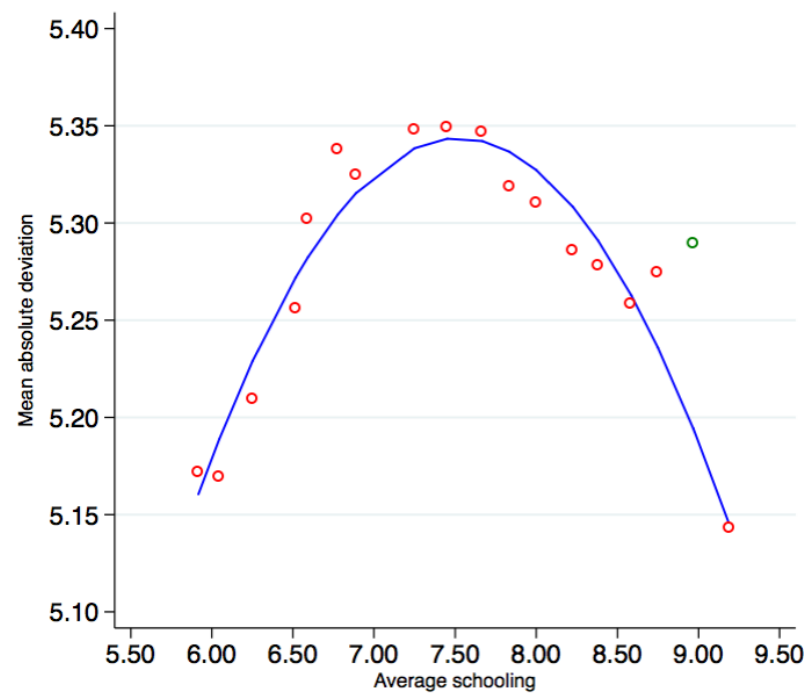

Figure 8. Relation between the mean absolute deviation and the average of schooling of occupied persons in Brazil, from 1992 to 2012

The point corresponding to 2011 is an outlier and was excluded when adjusting the parabola to the data. Examining, for each year, the proportion of occupied persons with zero schooling, it was observed that this proportion is exceptionally high in 2011, probably due to some type of error. This makes any measure of dispersion of schooling erroneously high in this year.

The relation between the mean and the dispersion of schooling will be used subsequently to help explaining the different evolution of the earnings inequality among persons occupied in the agricultural sector ${ }^{15}$.

The curve illustrated in Figure 8 reaches a maximum when the average schooling roughly equals 7.5 years. As the average schooling in the non-agricultural sector is already above this value and as in the agricultural sector this average is well below, the trend of the schooling dispersion is radically different in the two sectors.

Figure 7 and Figure 9 show that in the period 19922012, as the average schooling increases, the mean absolute difference $(\Delta)$ of schooling tends to increase in the agricultural sector but tends to decrease in the nonagricultural sector. This has important implications for the evolution of the inequality of the earnings distribution in both sectors.

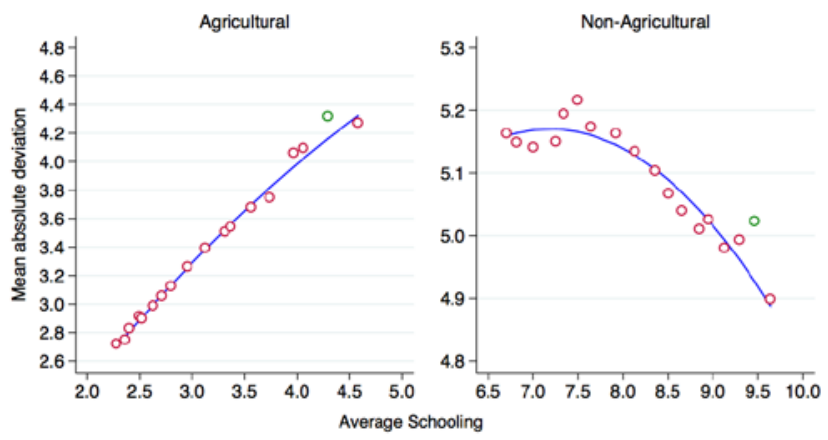

Figure 9. Relationship between the mean absolute deviation and the average schooling for agricultural and non-agricultural sectors from 1992 to 2012

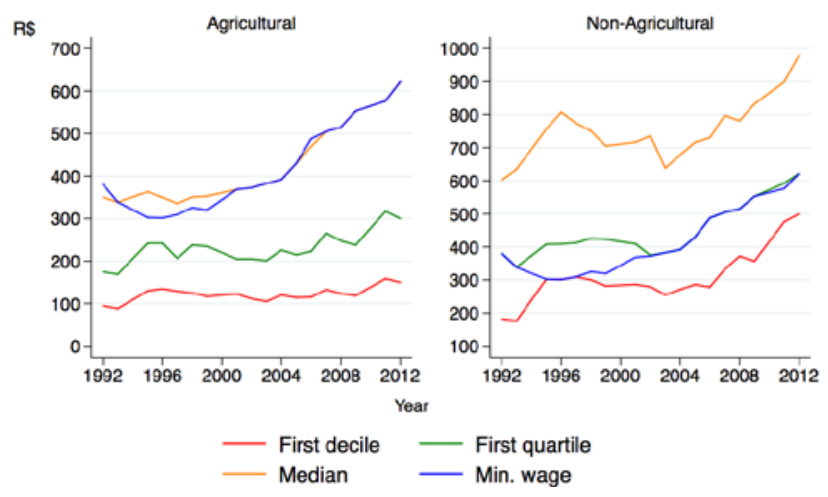

Figure 10. Evolution of the real minimum wage and of three quantiles (the first decile, the first quartile and the median) of occupied persons earnings’ distribution in Brazil, from 1992 to 2012

Figure 10 highlights the evolution of the values of three quantiles of the earnings distribution in the agricultural and the non-agricultural sectors: the first decile, the first quartile and the median (which is also the second quartile or the fifth decile). Since the earnings are much lower in the agricultural sector, different scales were used on the

\footnotetext{
${ }^{15}$ Barros, Carvalho, Franco and Mendonça (2010) used the relation between standard deviation and mean schooling to explain the decline in inequality in the distribution of income in Brazil, evaluating the contribution of changes in schooling to reduce the Gini index from 2001 to 2007.
} 
ordinate axis. In the two graphs that compose Figure 10, a fourth line (in blue) representing the evolution of the real value of the minimum wage (MW) was included. In the agricultural sector, from 2001 to 2012, the MW is generally equal to the median. In the non-agricultural sector, on the other hand, the MW generally coincides with the first quartile from 2002 to 2012 and with the first decile in 1995, 1996 and $1997^{16}$.

Figure 11 shows the evolution of four inequality measures of the earnings distribution in the two sectors: the Gini index, Theil's $L$ and $T$ indices and the proportion of total earnings received by the richest tenth.

In Figure 2 it was possible to observe that, from 1992 to 2001, the Gini index in the agricultural sector is at times higher and at other times lower than the non-agricultural sector's index. As the inequality decreases systematically in the non-agricultural sector, from 2002 on the Gini index in the agricultural sector is systematically higher than in the non-agricultural sector. Figure 11 shows a very similar picture of the values of Theil's $L$ index in the two sectors. As the Theil's $T$ index is more sensitive to changes in the upper tail of the distribution, the fact that this index is always higher in the agricultural sector indicates that this sector is characterized by income concentration in its upper tail. Note that the proportion of the total income appropriated by the richest tenth is also systematically higher in the agricultural sector than in the nonagricultural sector.

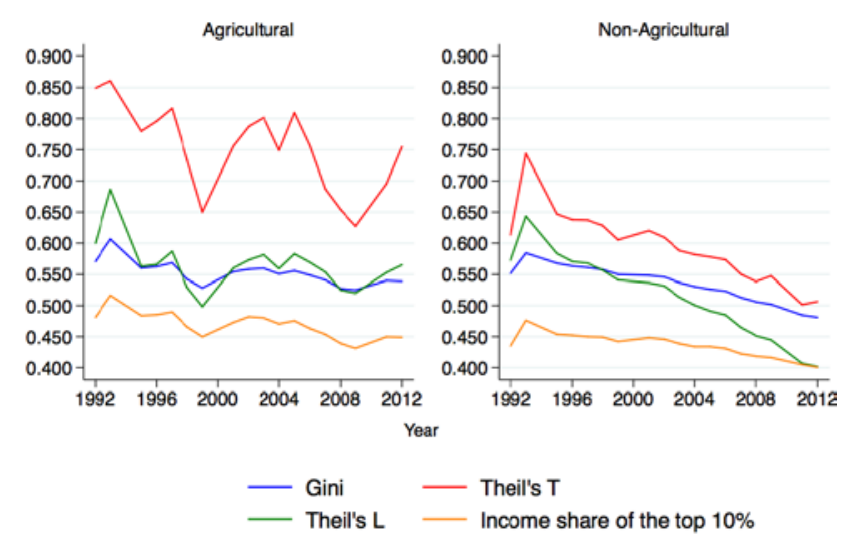

Figure 11. Inequality measures of the occupied persons earnings' distribution in Brazil, from 1992 to 2012

The higher concentration of income in the upper tail of the distribution in the agricultural sector may be due, in part, to the inclusion of land rent, profits and interest in farmers' "earnings". In the non-agricultural sector this may happen only in the case of some of the self-employed or family enterprises. Interest and dividends are informed in a different question of the survey questionnaire.

Figure 12 contrasts the participation in the total earnings of the richest one hundredth $(1+)$ and the poorest half $(50-)$. The proportion of the total income appropriated by the richest $1 \%$ is always much greater in the agricultural sector.

In the non-agricultural sector, in 2003, the share of the richest $1 \%$ was even greater than the share of the poorest $50 \%$ (both around 14\%). From this year on, the share of

\footnotetext{
${ }^{16}$ For a detailed analysis of the impact of the MW on earnings of agricultural employees, see Oliveira and Hoffmann (2013b).
}

the poorest 50\% increases systematically, reaching $20.0 \%$ in 2012 , when the share of the richest $1 \%$ was $11.7 \%$.

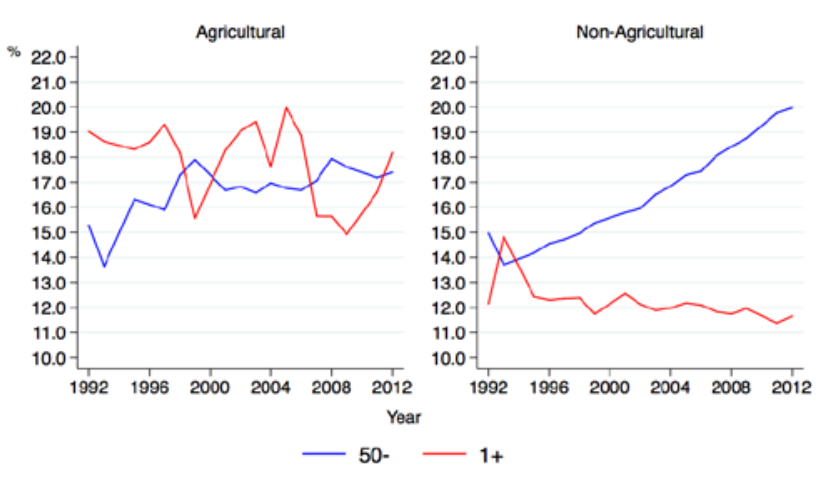

Figure 12. Percentage of the total income appropriated by the richest $1 \%$ (1+) and the poorest 50\% (50-) in the occupied persons earnings' distribution in Brazil, from 1992 to 2012

In the agricultural sector the share of the poorest $50 \%$ also showed an increasing trend, but less intense and much more irregular. Only in 1999 and from 2007 to 2011, the share of the poorest $50 \%$ was higher than the share of the richest $1 \%$ in total agricultural earnings.

\section{Evolution of the Effects Estimated Fitting Earnings Equations for each Year}

The estimation of earnings equations is a wellestablished methodology to analyze how different factors (age, education, gender, etc.) affect earnings. Using the data described in the previous section and the Weighted Least Squares method (WLS), earnings equations were fitted for each year from 1992 to 2012 in order to analyze how the effect of the factors varied over this period.

The general regression model is given by:

$$
\ln Y_{j}=W_{j}=\alpha+\sum_{i} \beta_{i} X_{i j}+u_{j}
$$

The dependent variable $W_{j}$ is the natural logarithm of monthly earnings from all jobs per occupied person (given the restrictions described at the beginning of the previous section), $\alpha$ and $\beta_{i}$ are model parameters, $X_{i j}$ indicates the explanatory variables (characteristics of the persons and their occupations) and $u_{j}$ represents a random error with the usual statistical properties.

The explanatory variables are described in the following list.

a. A binary variable with value 1 for females and value 0 for males.

b. The age of the person, measured in decades, and the square of such number of decades. Age is measured in decades only to avoid extremely small coefficients. Denominating as $c_{1}$ and $c_{2}$ the estimates of the coefficients for age and for the square of age, respectively, the estimate of the age in which earnings reach their maximum value is $-10 c_{1} /\left(2 c_{2}\right)$ years.

c. Schooling of the person $(E)$, varying from 0 to 17 . Values 0 to 14 correspond to the level of schooling achieved by the person, and the value 17 is attributed to persons with 15 or more years of schooling. As rates of 
return for schooling show a very substantial change around 10 years of schooling, a binary variable $Z$ was created, with $Z=0$ for $E \leq 10$ and $Z=1$ for $E>10$. Thus, the model for the earnings equation includes terms $\beta_{1} E$ and $\beta_{2} Z(E-10)$, corresponding to a polygonal with vertex at $E=10$, declivity $\beta_{1}$ for $E \leq 10$ and declivity $\beta_{1}+\beta_{2}$ for $E>10$. Being $b_{1}$ and $b_{2}$ the estimates of $\beta_{1}$ and $\beta_{2}$, the estimate of the rate of return for schooling is $100\left[\exp \left(b_{1}\right)-1\right]$ for $E \leq 10$ and is $100\left[\exp \left(b_{1}+b_{2}\right)-1\right]$ for $E>10$.

d. The logarithm of weekly working hours in all jobs. The coefficient of this variable is the income elasticity of earnings in relation to the number of hours worked per week.

e. Five binary variables to distinguish six regions of the country: North; Northeast (adopted as the reference category); the grouping of the tree states of Minas Gerais, Espírito Santo and Rio de Janeiro; São Paulo state; South; and Midwest.

f. A binary variable equal to 1 when the person is a resident in rural areas and equal to 0 when the person resides in urban areas ${ }^{17}$.

g. Three binary variables to distinguish between four categories of skin color, according to what the respondent declared in the survey: white (category adopted as reference), black, Asian, and mulatto or mixed.

h. Finally, three binary variables to distinguish four occupational positions: employees with a labor contract (taken as reference), employees without a labor contract, self-employed and employers.

In the earnings equations, if $Y$ is the value of earnings and $X$ is a continuous explanatory variable, and if the value of the all other terms of the equation is indicated by $\Theta$, it is possible to write

$$
\ln Y=\beta X+\Theta
$$

Keeping the value of all other explanatory variables, it follows that

$$
\begin{array}{r}
\frac{d Y}{Y}=\beta d X \text { or, approximately, } \\
\frac{\Delta Y}{Y}=\beta \Delta X
\end{array}
$$

The first term of this equation represents the relative variations in earnings, which corresponds to the concept of inequality in the distribution of earnings. Thus, it can be verified that the inequality tends to increase with the absolute value of the coefficient $\beta$ and with the variations (dispersion) of $X$.

It is important to keep in mind that, in the earnings equation, it is the dispersion of schooling (measured by standard deviation or by the mean absolute difference), and not its inequality, that is directly associated with the earnings' inequality.

\footnotetext{
${ }^{17}$ It is important to mention the fact that the delimitation of urban areas was updated in the 2000 Census, obeying the laws of each municipality. So, the definition of urban areas remained fixed in the survey (PNAD) from 1992 to 1999, suffering a change in 2000, remaining fixed again from 2001 to 2009 and changing again in 2010. When interpreting the corresponding coefficient and its evolution it is necessary to take these changes into account.
}

If $b$ is the estimated coefficient of a binary variable, the effect of this variable is defined as the percentage variation in the earnings value when the binary variable changes from zero to one, as follows:

$$
100[\exp (b)-1]
$$

In the case of a continuous variable the same expression provides the percentage increase in the expected earnings due to a unitary increase in the explanatory variable.

Figure 13 to Figure 18 show the evolution of the effects of the selected explanatory variables from 1992 to 2012.

The graph for the non-agricultural sector in Figure 13 shows that the rate of return to schooling up to 10 years shows a clear downward trend and the rate of return to schooling that is above the threshold of 10 years increased until 2002 and then started to decrease.

It was observed, in Table 6, that the dispersion of schooling in the non-agricultural sector (measured by the mean absolute difference) tends to decrease from 1998 on. Thus, from 2002 on, schooling is contributing to reduce inequality in the earnings' distribution in the nonagricultural sector, due to its lower dispersion and also to the reduction in the rate of return to schooling for those with relatively high schooling (over 10 years).

In the agricultural sector a somewhat similar behavior can be observed regarding the rate of return to schooling for persons with more than 10 years of formal education, although the peak of this rate occurred in 2005 and not 2002, as observed for the non-agricultural sector. Regarding the dispersion of schooling, however, the phenomenon is totally different because, as was seen earlier, the dispersion of schooling in the agricultural sector is increasing and contributes to increase the inequality of the earnings' distribution.

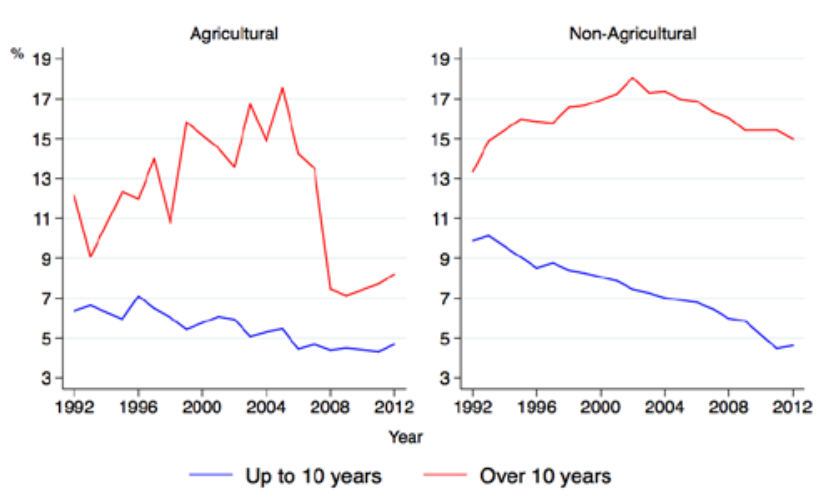

Figure 13. Rate of return up to 10 years of schooling and over 10 years of schooling for occupied persons in Brazil, from 1992 to 2012

Figure 14 shows the evolution of the effect of being black, mulatto or female, a white male taken as the reference category. It can be seen that the absolute effect of being female is diminishing in both sectors, and it is always greater in the non-agricultural sector. The effects of being black or mulatto are quite similar and unfortunately there is no trend of reduction.

It is simplistic to interpret the effect of being black or mulatto as resulting exclusively from discrimination since, as shown by Figure 15, the effect of being Asian is positive, and it would be strange to consider that there is "discrimination" in favor of Asians. It is worth noting that the value of the effect of being Asian shows a downward trend from 1992 to 2009 in both sectors. 


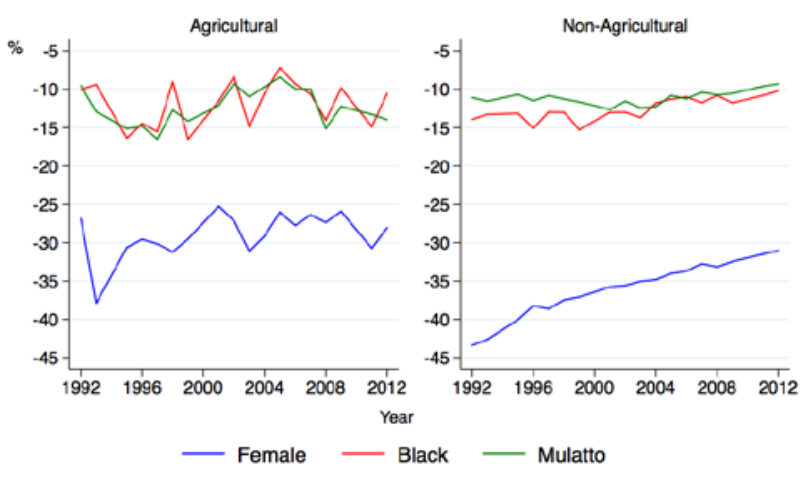

Figure 14. Effect of being female, black or mulattoon occupied persons' earnings in Brazil, from 1992 to 2012
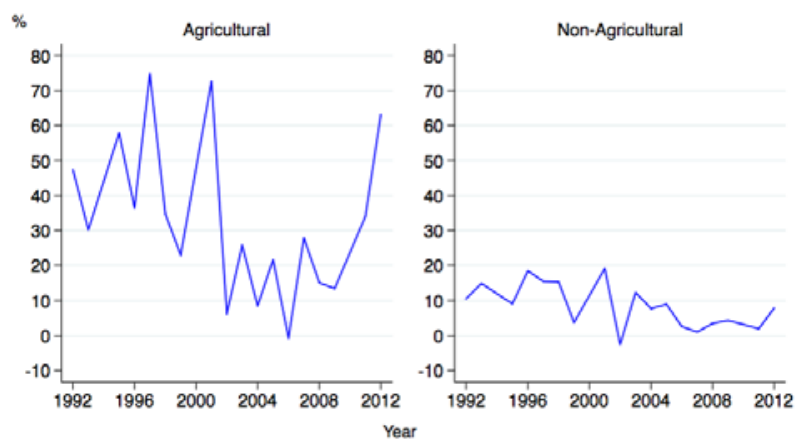

Figure 15. Effect of being Asian on occupied persons' earnings in Brazil, from 1992 to 2012

As the poorest region of the country was taken as the reference category (Northeast), the effects associated to the other regions are always positive, as shown in Figure 16. In the graph for the non-agricultural sector, it is observed that the effect associated to São Paulo (SP), which was initially well above the other regions, tends to decrease, contributing to reduce interregional inequality. The same does not occur in the agricultural sector.

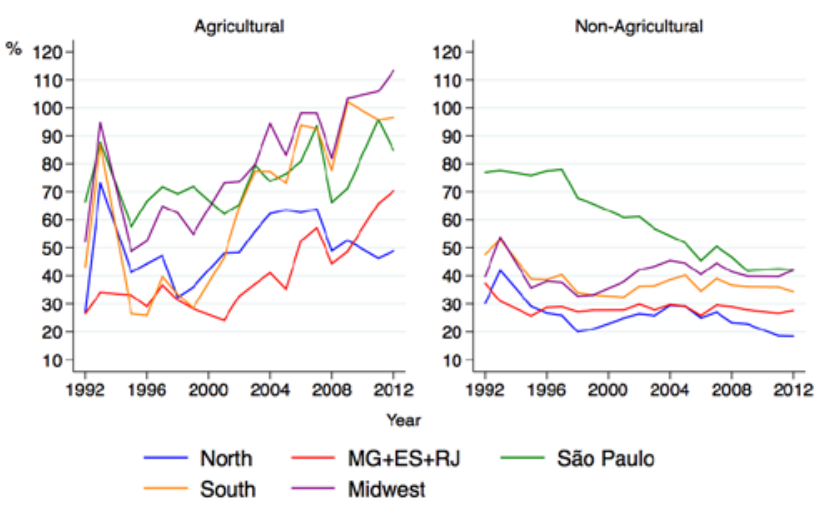

Figure 16. Effect associated to the regions (Northeast taken as reference) on occupied persons' earnings in Brazil, from 1992 to 2012

Figure 17 shows the evolution of the effects of being self-employed or employee without labor contract compared to the reference category (employee with labor contract). These effects are always more negative in the agricultural sector. It should be noted that from 1996 on the effect of not having a labor contract tends to be increasingly negative in the agricultural sector. Certainly, this is related to the growth of the real value of the minimum wage in the period and also to the fact that this growth benefits more the employees with a labor contract (see Oliveira and Hoffmann, 2013 b). In the nonagricultural sector, the evolution of the effect of not having a labor contract is quite different.
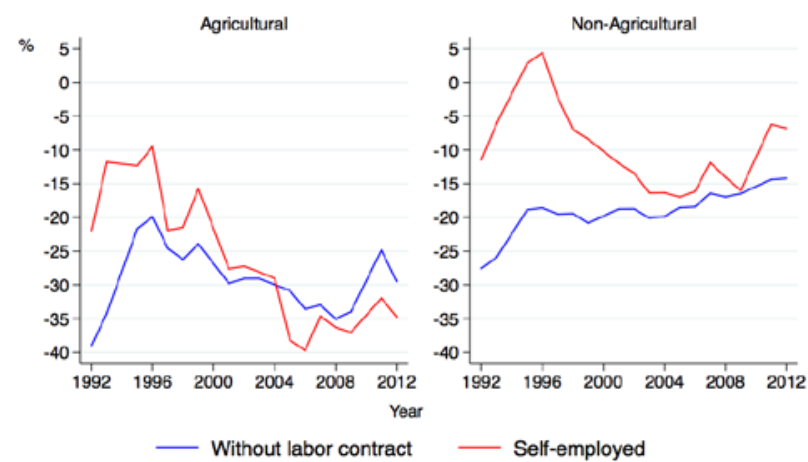

Figure 17. Effect of not having a labor contract or of being selfemployed (in comparison with an employee with a labor contract) on occupied persons' earnings in Brazil, from 1992 to 2012

Figure 18 shows that the effect of having residence in rural areas is stronger in the non-agricultural sector, but in both cases its absolute value shows a decreasing trend, indicating some convergence between rural and urban areas (still with great disadvantage for rural areas).
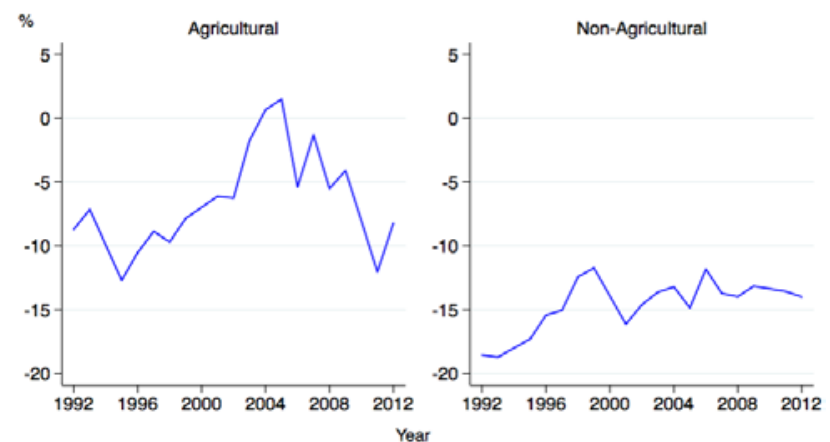

Figure 18. Effect of rural residence on occupied persons' earnings in Brazil, from 1992 to 2012

\section{Earnings' Inequality among Six Regions or among the 27 Brazilian Federation Units}

Figure 19 shows the evolution of the components of the Theil's indexes ( $T$ and $L$ ) related to the earnings inequality between six regions or between the 27 Brazilian Federation Units (FUs, including 26 States and the Federal District). The different behavior of the inter-regional inequality in the two sectors is evident, and only in the non-agricultural sector a clear reduction of the interregional inequality after 1997 can be observed.

Figure 20 shows the evolution of the inequality between 6 regions or between 27 Federal Units measured as percentages of total inequality of the occupied persons' earnings distribution. Even with total inequality in the non-agricultural sector decreasing since 1993, there is, from 1998 on, a declining trend in the participation of the inequality between regions or between Federal Units. In the agricultural sector, however, these percentages show an increasing trend. The different behavior is, at least partially, related to the different effect of the MW 
discussed previously when commenting Figure 10 and Figure 17 and to the greater importance of the selfemployed in agriculture, but more research is necessary for a better explanation of the facts. The regional inequality is lower and declining in the non-agricultural sector, indicating that this national labor market is becoming more integrated, but in agriculture the regional heterogeneity is increasing.

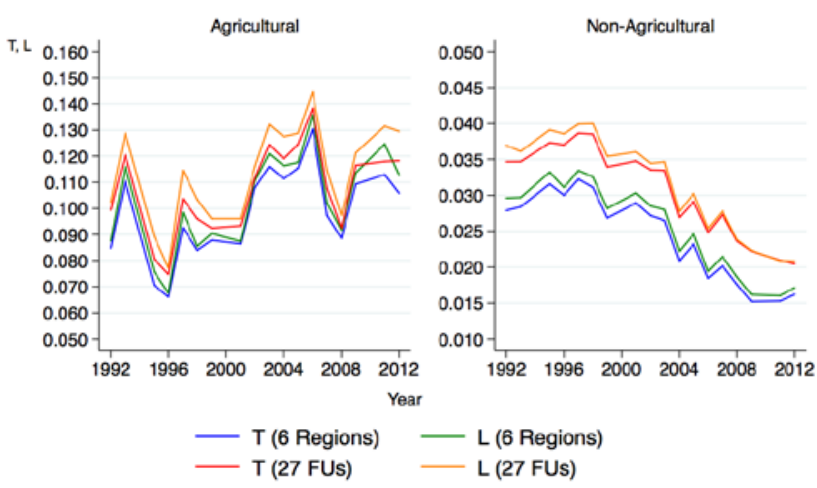

Figure 19. Theil's $L$ and $T$ indexes of earnings of occupied persons' inequality between six regions or between 27 Federation Units in Brazil, from 1992 to 2012

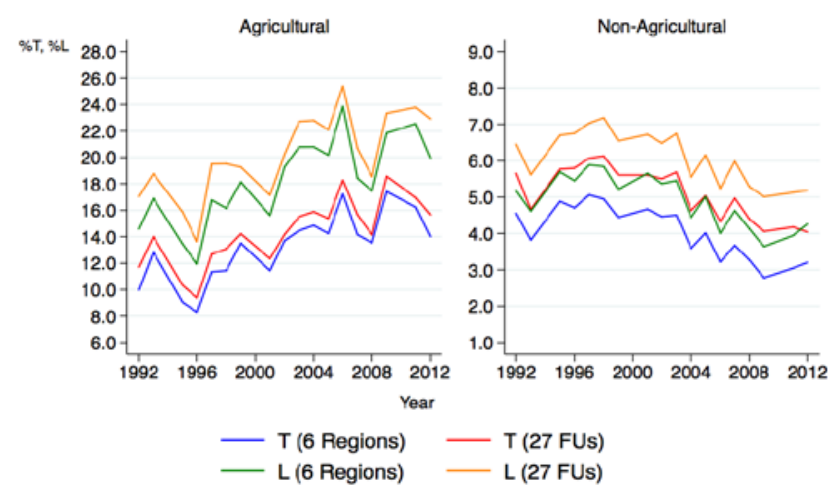

Figure 20. Percentages of the Theil's $T$ and $L$ indexes of occupied persons' earnings distribution related to the inequality between six regions or between 27 Federation Units in Brazil, from 1992 to 2012

\section{Conclusions}

The data from the national households sample survey (PNAD) show that the agricultural sector presents a differentiated behavior considering changes in the income distribution in Brazil. Regarding the per capita household income, although in the 2001-2009 period the reduction rate of inequality among agricultural households is similar to the one observed in Brazil as a whole, the determinants associated with this reduction are clearly different in the agricultural sector. Considering all households, between 2001 and 2009 20.0\% of the reduction in the Gini index of per capita household income distribution can be attributed to the IBF component, which includes government transfers such as the BolsaFamília (besides interests, dividends and other incomes). In the case of agricultural households this percentage reaches $44.7 \%$.

Another important result is that, in the case of the agricultural sector, the contribution of the share of employees' earnings (EMP) in reducing inequality is substantially lower compared to Brazil (21.3\% versus 49.2\% between 2001 and 2009).

Concerning the income of occupied persons, the reduction in inequality is less intense and more irregular in the agricultural sector compared to the non-agricultural sector. The different factors that determine the income of occupied persons also presented distinct behaviors for the agricultural and non-agricultural sectors. The evolution of the dispersion of schooling is radically different for the two sectors. In the period 1998-2012, as the average schooling increases, the dispersion tends to grow in the agricultural sector but tends to decrease in the nonagricultural sector.

For the persons occupied in the agricultural sector the real minimum wage is close to the median of earnings (from all jobs). On the other hand, in the non-agricultural sector the minimum wage generally coincides with the first quartile of the earnings distribution over the period 2002-2012.

Analyzing the evolution of the effects estimated by fitting earnings equations for each year from 1992 to 2012, it was found that the effects of being black or mulatto (taking a white person as basis) are very similar in both sectors and show no tendency to decrease. The earnings difference between men and women decreased, especially in the agricultural sector, but women are still in disadvantage.

The differences associated with geographic location are still strong, but in the case of the non-agricultural sector there is a convergence trend, with reduction in inequality among six regions or among the 27 Federation Units from 1997 on. This is not observed for the agricultural sector, which actually presents an increasing trend of the measures of inequality among the six regions or the 27 Federation Units.

Finally, it is worth mentioning that, from 1996 to 2009, the effect of being employed without a labor contract (taking the employees with labor contract as the reference category) tended to be increasingly negative in the agricultural sector. The effect of being self-employed in agriculture shows a similar behavior. These facts are associated with changes in the real minimum wage, which benefited more the employees with a labor contract.

\section{References}

[1] Barros, R. P., Carvalho, M., \& Franco, S. (2007). Afinal, as mudanças nos benefícios sociais ocorridas a partir de 2001 tiveram influência sobre a queda na desigualdade e na pobreza? in: Análise da Pesquisa Nacional por Amostra de Domicílios-PNAD 2005 Pobreza e Desigualdade, MTE/CGEE (Ed.), Brasília: MTE, CGEE (pp. 185).

[2] Barros, R. P., Carvalho, M., Franco, S., Mendonça, R. (2010). Markets, the state and the dynamics of inequality: Brazil's case study, in: The New Dynamics of Income Inequality in Latin America, López-Calva, L., Lustig, N. (Eds.), Washington DC: Brookings Institution.

[3] Barros, R. P., Foguel, M. N., Ulyssea, G. (2006). Desigualdade de renda no Brasil: uma análise da queda recente (Vol. 1). Brasília: IPEA.

[4] Barros, R. P., Foguel, M. N., Ulyssea, G. (2007). Desigualdade de renda no Brasil: uma análise da queda recente (Vol. 2). Brasília: IPEA.

[5] Barros, R. P., Franco, S., Mendonça, R. (2007). A recente queda na desigualdade de renda e o acelerado progresso educacional brasileiro na última década, in:Desigualdade de renda no Brasil: 
uma análise da queda recente (Vol. 2), Barros, R. P., Foguel, M. N. \&Ulyssea, G. (Eds.), Brasília: IPEA.

[6] Daré, E. F. (2010). Desigualdade da distribuição da renda no Brasil: a contribuição dos rendimentos do funcionalismo público. (MS), UniversityofCampinas, Campinas, SP, Brazil.

[7] Feijó, R. L. C. (2009). O efeito do título de propriedade da terra na determinação da renda rural. Paperpresentedatthe47Conferenceof Sociedade Brasileira de Economia, Administração e Sociologia Rural, Porto Alegre - RS - Brazil.

[8] Hoffmann, R. (1988). A subdeclaração dos rendimentos. São Paulo em Perspectiva, 2 (1).

[9] Hoffmann, R. (2001). A distribuição da posse da terra no Brasil de acordo com as PNAD de 1992 a 1999,in: Transformações da Agricultura e Políticas Públicas,Conceição, J. C. \&Gasques, J. G. (Eds.), Brasília: IPEA.

[10] Hoffmann, R. (2006). Transferências de renda e a redução da desigualdade no Brasil e cinco regiões entre 1997 e 2004. Econômica,8 (1): 55-81.

[11] Hoffmann, R. (2007). Transferências de renda e redução da desigualdade no Brasil e em cinco regiões, entre 1997 e 2005, in: Desigualdade de renda no Brasil: uma análise da queda recente (Vol. 2), Barros, R. P., Foguel, M. N. \&Ulyssea, G. (Eds.), Brasília: IPEA.

[12] Hoffmann, R. (2009). Desigualdade da distribuição da renda no Brasil: a contribuição de aposentadorias e pensões e de outras parcelas do rendimento domiciliar per capita. Economia $e$ Sociedade, 18 (1 (35)).

[13] Hoffmann, R. (2010). Desigualdade da renda e das despesas per capita no Brasil, em 2002-2003 e 2008-2009, e avaliação do grau de progressividade ou regressividade de parcelas da renda familiar. Economia e Sociedade, 19 (3 (40)): 647-661.

[14] Hoffmann, R. (2011). The evolution of income distribution in Brazil, in: The Economies of Argentina and Brazil: A Comparative Perspective, Baer, W.\& Fleischer, D. (Eds.), London, UK: Edward Elgar Publishing.

[15] Hoffmann, R. (2013a). Transferências de renda e desigualdade no Brasil (1995-2011). In Campello, T.\& Neri, M. C. (ed.) Programa Bolsa Família: uma década de inclusão e cidadania. Brasília, IPEA, p. 207-216.

[16] Hoffmann, R. (2013 b). How to measure the progressivity of an income component. Applied Economic Letters, 20 (4): 328-331.

[17] Hoffmann, R., Ney, M. G. (2004). Desigualdade, escolaridade rendimentos na agricultura, indústria e serviços, de 1992 a 2002. Economia e Sociedade, 13 (2 (23)).

[18] Hoffmann, R., Ney, M. G. (2008). A recente queda da desigualdade de renda no Brasil: análise de dados da PNAD, do Censo Demográfico e das Contas Nacionais. Econômica, 10 (1).

[19] Hoffmann, R., Ney, M. G. (2010). Estrutura fundiária e propriedade agrícola no Brasil, grandes regiões e Unidades da Federação. Brasília: Ministério do Desenvolvimento Agrário MDA.
[20] Hoffmann, R., Oliveira, R. B. (2012). The evolution of income distribution in Brazil: different characteristics of the agricultural sector: Paper presented at the Triennial Conference of the International Association of Agricultural Economists, Foz do Iguaçu, Brazil. Available at http://purl.umn.edu/127673

[21] IPEA. (2009). Carga horária de trabalho: evolução e principais mudanças no Brasil. Brasília: Instituto de Pesquisa Econômica Aplicada, Comunicado da Presidência n. 24. Brasília: IPEA.

[22] IPEA. (2010). PNAD 2008: Primeiras análises - O setor rural, Comunicados do IPEA n. 42. Brasília: IPEA.

[23] Lemos, S. (2009). Minimum wage effects in a developing country. Labour Economics, 16 (2)

[24] Lerman, R. I., Yitzhaki, S. (1985). Income Inequality Effects By Income Source - A New Approach And Applications To The United-States. Review of Economics and Statistics, 67 (1).

[25] Lerman, R. I., Yitzhaki, S. (1995). Changing Ranks and The Inequality Impacts Of Taxes And Transfers. National Tax Journal, 48 (1).

[26] Lorel, B. (2008). Assessing Brazilian educational inequalities. RevistaBrasileira de Economia, 62 (1).

[27] Neumark, D., Cunningham, W., Siga, L. (2006). The distributional effects of minimum wages in Brazil, 1996-2001. Journal of Development Economics, 80 (1).

[28] Ney, M. G., Hoffmann, M. G. (2003). Desigualdade de renda na agricultura; o efeito da posse da terra. Economia, 4 (1).

[29] Ney, M. G., Hoffmann, R. (2003). Origem familiar e desigualdade de renda na agricultura. Pesquisa e Planejamento Econômico, 33 (3).

[30] Ney, M. G., Hoffmann, R. (2011). Agricultura e a recente queda da desigualdade de renda no Brasil, in:Políticas Públicas e Desenvolvimento,Mattos, L. B., Teixeira E. C. \& Fontes R. M. (Eds.), Viçosa-MG: UFV/DER/DEE.

[31] Oliveira, R. B. (2010). Desigualdade de rendimentos entre os empregados na agricultura brasileira, 1992-2008. (MS), University of Campinas, Campinas, SP, Brazil.

[32] Oliveira, R. B., Hoffmann, R. (2013a). Determinantes do rendimento dos empregados temporários e permanentes na agricultura brasileira em 2009. Revista de Economia Agrícola 59 (1).

[33] Oliveira, R. B., Hoffmann, R. (2013b). Desigualdade de rendimentos entre os empregados na agricultura brasileira de 1992 a 2009: o efeito do salário mínimo. Revista Econômica do Nordeste, 44 (1).

[34] Soares, S. S. D.(2006). Análise de bem-estar e decomposição por fatores da queda na desigualdade entre 1995 e 2004. Econômica, 8 (1): 83-115.

[35] Soares, F. V., Soares, S., Medeiros, M. \& Osório, R. G. (2006) Cash transfer programmesin Brazil: impacts on inequality and poverty. Working paper n. 21. Washington DC: International Poverty Centre - UNPD.

[36] Souza, P., Baltar, P. (1979). Salário mínimo e taxa de salários no Brasil. Pesquisa e Planejamento Econômico, 9. 